\title{
Sugars in Staple Type Sweet Potatoes as Affected by Cooking and Storage ${ }^{1}$
}

\begin{abstract}
Franklin W. Martin ${ }^{2}$
ABSTRACT

Staple type sweet potatoes with little or no sweetness after cooking, and that appear to be suitable as everyday starchy foods, have been developed. The reducing and non-reducing sugar contents of these cultivars before and after microwave baking, and before and after storage, were compared with those of conventional sweet cuitivars. The non-reducing sugar content is reduced slightiy by baking in most cultivars. The reducing sugar content greatly increases with baking except in a few staple types. A series of varieties can be distinguished with respect to sugar changes. Storage at ambient temperature for 1 to 2 months results in slight increases in non-reducing sugar contents and lithe change in reducing sugars. Sugar contents before or after baking or storage are not related to dry matter, starch or protein contents. However, staple and sub staple cultivars are characterized by a drier mouthfeel.
\end{abstract}

\section{INTRODUCTION}

The carbohydrates of sweet potato storage roots account for 80 to $90 \%$ of their dry weight (6), and consist principally of sugars and starch, and of smaller amounts of cellulose, pectins, and hemicelluloses. The relative composition varies not only with cultivars and maturity of the root, but also with time in storage and with cooking. During storage much of the starch is broken down enzymatically into simple sugars, from which sucrose is synthesized (1). During cooking starch is hydrolyzed with a subsequent increase of maltose and dextrins (12). Picha ${ }^{3}$ believes the increase of reducing sugars in a relatively few minutes of cooking is due to a non-enzymatic hydrolysis of starch. Because of the ready transformation of starches to sugars in sweet potato, it is possible that preparing the sweet potato for analysis, by cutting and drying, for example, can in itself influence the composition. Consequently, samples that are prepared without careful controls to avoid not only metabolic activity but also externally induced hydrolysis are probably unreliable. Jenkins and Moore (4) have shown that refrigerated samples awaiting analysis increased significantly in reducing sugar content in 7 hours. No reliable data are available on the sugar contents of uncooked sweet potatoes.

Carbohydrate contents of sweet potatoes are associated with taste and mouthfeel, and may be related to flatulence as well. The sweetness of the cooked sweet potato varies. Whereas a very sweet flavor is desired in the

\footnotetext{
${ }^{2}$ Manuscript submitted to Editorial Board February 7, 1985.

${ }^{2}$ Tropical Agriculture Research Station, Southern Region, Agricultural Research Service, Science and Education, U.S. Department of Agriculture, Mayagüez, P.R.
}

${ }^{3}$ D. Picha, personal communication. 
moist, orange-fleshed sweet potatoes of the southern United States (8), low sweetness is generally considered desirable for a staple type sweet potato in the tropics $(3,11)$. The relative "moistness" or "dryness," as perceived in the mouth, appears to be correlated with viscosity (7), and may be related to starch and dextrin content (12) or to changes in starch and protopectin contents (9). The nature of mouthfeel in the sweet potato cannot be said to be fully elucidated. On the other hand, claims that sweet potatoes cause flatulence $(10)$ are not substantiated by research data. In sweet potatoes there may be little or no oligosaccharides, the sugars believed to be responsible for flatulence in the bean (5). However, hydrolysis of starch results in short chain dextrins that might be difficult to digest, and thus cause flatulence in the lower intestine. It is chiefly for taste preference or to develop an everyday staple food that low sugar sweet potatoes are desired. Such varieties can be said to be only now in the developmental stage. They may or may not be similar to Asian type high starch industrial varieties, but they are definitely less sweet than the US industrial varieties Pelican Processor and White Star. Considerable breeding is still desirable for the production of fine nonsweet staple-type sweet potatoes.

The purpose of this study was to characterize the sugar content before and after cooking and before and after storage of some new prototype non-sweet or low-sweet sweet potatoes as compared to normal cultivars.

\section{MATERIALS AND METHODS}

The sweet potatoes in this study were selected as seedlings either from introduced seeds or from our own breeding populations, or commercial cultivars used as controls. The sweet potatoes were classified as dessert (very sweet), tropical (low sweet), substaple (slightly sweet), or staple (not sweet) on the basis of repeated cooking tests and familiarity. Table 1 gives origin and some characteristics of the cultivars. It should be noted that only three of the cultivars are considered staple (non-sweet).

Freshly harvested tuberous roots of 16 cultivars were cut into $200 \mathrm{~g}$ portions and cooked $10 \mathrm{~min}$ in a microwave oven at maximum energy setting. This time had been predetermined as adequate for a well-cooked sweet potato. Samples of the cooked sweet potato and an uncooked control were thinly sliced and dried for 16 hours in a forced-draft oven at $40^{\circ} \mathrm{C}$. Levels of reducing and non-reducing sugars and proteins were measured by the methods of the American Chemical Society (2).

Storage roots of five of the cultivars were stored at ambient temperature $\left(24-28^{\circ} \mathrm{C}\right)$ and relative humidity $(30-95 \%)$ for 1 or 2 months. Samples of $500 \mathrm{~g}$ from the stored roots and unstored controls were frozen until the end of the experiment. Then all frozen samples were thawed, sliced, and immediately dried as previously described. 


\section{RESULTS AND DISCUSSION}

The 16 cultivars ranged in starch content from 15.4 to $32.0 \%$, in dry matter from 22.0 to $45.0 \%$, and in protein from 2.8 to $8.6 \%$ (table 1 ). There was no correlation of starch, dry matter, or protein content with sugar content among these varieties. On the other hand, the cultivars classified as staple or substaple were drier in mouthfeel than dessert and tropical varieties.

Table 2 summarizes the sugar content of the cultivars before and after cooking. With respect to non-reducing sugars, chiefly sucrose, content

TABLE 1.-Sweet potato cultivars used for tests for sugar and some characteristics at harvest

\begin{tabular}{|c|c|c|c|c|c|c|c|}
\hline Cultivar & Source & $\begin{array}{c}\text { Type } \\
\text { of cultivar }\end{array}$ & $\begin{array}{l}\text { Flesh } \\
\text { color }\end{array}$ & $\begin{array}{l}\text { Percent } \\
\text { dry matter }\end{array}$ & $\begin{array}{c}\text { Starch } \\
\text { content }\end{array}$ & Protein & Mouthfeel \\
\hline & & & & & $\%$ & $\%$ & \\
\hline Gem & United States & Dessert & Orange & 22.0 & 15.4 & 4.1 & 5 \\
\hline Frita & Seeds, Nigeria & Tropical & White & 30.6 & 26.5 & 3.8 & 3 \\
\hline Miguela & Puerto Rico & Tropical & White & 35.0 & 29.8 & 4.0 & 3 \\
\hline Nutty & Seeds, breeding & Tropical & $\begin{array}{l}\text { light } \\
\text { yellow }\end{array}$ & 32.6 & 21.0 & 8.6 & 3 \\
\hline Sneaky & Seeds, Papua NG & Tropical & White & 43.0 & 22.0 & 6.1 & 3 \\
\hline Spud & Seeds, Nigeria & Tropical & White & 44.6 & 13.6 & 3.9 & 3 \\
\hline Toquecita & Seeds, Papua NG & Tropical & White & 38,2 & 24.8 & 4.4 & 2 \\
\hline Trompo Negro & Seeds, Nigeria & Tropical & Purple & 45.0 & 28.4 & 4.6 & 3 \\
\hline Bun & Seeds, Papua NG & Substaple & White & 30.4 & 24.4 & 5.7 & 3 \\
\hline Francia & Seeds, Papua NG & Substaple & White & 31.2 & 22.2 & 5.6 & 3 \\
\hline Limonette & Seeds, Papua NG & Substaple & $\begin{array}{l}\text { Light } \\
\text { yellow }\end{array}$ & 39.6 & 28.6 & 4.1 & 2 \\
\hline Papota & Seeds, Nigeria & Substaple & White & 36.3 & 24.3 & 2.8 & 2 \\
\hline Viola & Seeds, Papua NG & Substaple & White & 39.1 & 31.0 & 3.4 & 3 \\
\hline Mojave & Seeds, Breeding & Staple & White & 36.9 & 32.0 & 4.2 & 2 \\
\hline Ninety-nine & Seeds, Papua NG & Staple & White & 31.7 & 22.1 & 3.3 & 1 \\
\hline Sahara & Seeds, Papua NG & Staple & White & 38.8 & 30.0 & 3.5 & 1 \\
\hline
\end{tabular}

${ }^{1}$ Rated 1-6, from very dry to very moist.

varied from 5.1 in a staple (Mojave) to $15.9 \%$ in a dessert type (Gem) sweet potato. The amount of non-reducing sugar was probably not significantly influenced by cooking, although in the three cultivars Sahara, Bun and Francia, part of the non-reducing sugars might have been hydrolyzed in cooking. On the other hand, reducing sugars were usually much lower in the uncooked sweet potatoes, ranging from 0.82 to $16.2 \%$. The amounts of reducing sugars were increased by cooking in all but the three cultivars Sahara, Ninety-nine and Limonette. Increase in reducing sugar in Mojave was low in amount although higher in percent. The increase in reducing sugar content was dramatic, reaching $400 \%$ in several 


\section{4}

JOURNAL OF AGRICULTURE OF UNIVERSTTY OF PUERTO RICO

cases. Such an increase is known to be due to the hydrolysis of starch on cooking (6), and has been thought to be a characteristic of all sweet potatoes.

Comparing sugar content of cooked sweet potatoes to classification by sweetness, shows that the staple and substaple cultivars had less total sugars than the tropical or dessert types. Whereas two cultivars had low reducing sugars after cooking, nevertheless, only one was perceived as nonsweet, because of its low total sugars even after cooking. However, other cultivars by virtue of relatively low sugar content, can be considered substaples. The cultivar Gem, with a total sugar content after cooking of $39.70 \%$, is typical of the dessert type.

TABLE 2,-Percent reducing and non-reducing sugars in cultivars of sweet potato before cooking and after microwave baking

\begin{tabular}{|c|c|c|c|c|c|c|}
\hline \multirow[b]{2}{*}{ Cultivar } & \multicolumn{3}{|c|}{ Redueing sugars } & \multicolumn{3}{|c|}{ Non-reducing sugars } \\
\hline & $\begin{array}{l}\text { Before } \\
\text { baking }\end{array}$ & $\begin{array}{l}\text { After } \\
\text { baking }\end{array}$ & $\begin{array}{c}\text { Percent } \\
\text { increase } \\
\text { on baking }\end{array}$ & $\begin{array}{l}\text { Before } \\
\text { baking }\end{array}$ & $\begin{array}{l}\text { After } \\
\text { balking }\end{array}$ & $\begin{array}{c}\text { Percent } \\
\text { increase } \\
\text { on baking }\end{array}$ \\
\hline Gem & 7.7 & 25.6 & 232 & 15.9 & 14.1 & $-10^{i}$ \\
\hline Frita & 2.8 & 15.6 & 457 & 10.4 & 10.2 & -2 \\
\hline Miguela & 3.2 & 22.1 & 590 & 8.1 & 7.1 & -12 \\
\hline Nutty & 8.5 & 22.1 & 160 & 5.3 & 6.8 & 28 \\
\hline Sneaky & 16.2 & 25.7 & 59 & 9.0 & 8.6 & -4 \\
\hline Spud & 4.6 & 18.8 & 309 & 7.9 & 7.6 & -4 \\
\hline Toquecita & 4.2 & 21.2 & 405 & 10.6 & 11.2 & 6 \\
\hline Trompo Negro & 2.5 & 22.1 & 784 & 9.5 & 8.6 & -9 \\
\hline Bun & 3.6 & 9.0 & 150 & 17.4 & 13.0 & -25 \\
\hline Francia & 7.6 & 12.8 & 68 & 11.4 & 9.2 & -19 \\
\hline Limonette & 3.7 & 3.8 & 3 & 13.3 & 13.0 & -2 \\
\hline Papota & 2.4 & 6.8 & 183 & 6.8 & 6.6 & -3 \\
\hline Viola & 3.9 & 12.6 & 223 & 10.8 & 10.8 & 0 \\
\hline Mojave & 3.2 & 5.7 & 78 & 5.1 & 5.4 & 6 \\
\hline Ninety-nine & 0.8 & 0.8 & 0 & 5.4 & 5.7 & 6 \\
\hline Sahara & 3.2 & 3.1 & -3 & 12.0 & 9.6 & -20 \\
\hline
\end{tabular}

${ }^{1}$ Decreases in sugar content are indicated by negative signs.

Non-reducing sugars in five cultivars increased during 1 or 2 months of storage (table 3). The magnitude of the increase was sufficient to influence taste in all five cultivars. However, increase in sugars due to storage was much less in magnitude than increase due to cooking. The only plausible explanation for this increase is that reducing sugars have been released and utilized in the synthesis of non-reducing sugars. In contrast, reducing sugars increased only slightly, if at all, during storage (table 3). The increase in non-reducing sugars could be expected to increase the total sweetness of cooked, stored sweet potatoes. However, 
the effect of storage on increase in sugars was quite small compared to that which occurs in conventional sweet potatoes (1). Cultivar differences in total sugar content before and after storage suggest that storage can affect their relative sweetness.

The finding of low sugar cultivars of sweet potato suggests that these can be used as everyday staples, that is, the principal starchy food used daily. Cultivar Ninety-nine approaches this ideal, but since it is the first of this type we have found, we are confident of producing still better cultivars. The mechanisms responsible for low sugar are not as yet evident, but might include differences in the starch molecule, making it more resistant to degradation, or in the enzyme system, making the enzymes less effective in hydrolysis of starch. It remains to be shown how useful these new cultivars may be in traditional and potential new uses.

TABLE 3.-Effect of storage on reducing and non-reducing sugar content of sweet potato cultivars

\begin{tabular}{|c|c|c|c|c|c|c|}
\hline \multirow{3}{*}{ Cultivar } & \multicolumn{6}{|c|}{ Age in months after harvest } \\
\hline & \multicolumn{2}{|r|}{0} & \multicolumn{2}{|c|}{1} & \multicolumn{2}{|r|}{2} \\
\hline & Red. & Non-red. & Red. ${ }^{1}$ & Non-red. ${ }^{1}$ & Red. & Non-red. \\
\hline Trompo Negro & 1.35 & 7.85 & 1.40 & 8.80 & 1.35 & 9.90 \\
\hline Frita & 4.95 & 5.20 & 6.90 & 7.40 & 4.50 & 13.60 \\
\hline Spud & 1.72 & 5.30 & 1.72 & 6.65 & 2.05 & 8.40 \\
\hline Papota & 2.42 & 6.75 & 2.56 & 7.85 & 3.68 & 6.90 \\
\hline Ninety-nine & 1.25 & 4.55 & 3.00 & 7.95 & 2.05 & 11.15 \\
\hline
\end{tabular}

${ }^{1}$ Red. = percent of sample which is reducing sugars. Non-red. = percent of sample which is nor-reducing sugars.

\section{RESUMEN}

Se han sido desarrollado batatas para uso diario con poca o ninguna dulzura después de cocinarlas. Se evaluaron los contenidos en azúcares reductores y no reductores de esas batatas antes y después de cocinarlas, asi como antes y después de almacenarlas. El contenido en azúcares no reductores disminuyó un poco al hornear la mayoría de las variedades. El de azúcares reductores aumentó considerablemente excepto en unas pocas variedades del tipo que se consume diariamente. Puede distinguirse una serie de variedades entre extremos. En almacenamiento a temperatura ambiente por 162 meses hubo aumentos pequeños en azúcares no reductores y muy poco cambio en azúcares reductores. Los contenidos en azúcares antes o después de cocinarlas o almacenarlas no están relacionados con el contenido en materia seca, almidón o proteína. Sin embargo, las batatas de consumo diario se caracterizan por una textura más seca. 


\section{IITERATURE CITED}

1. Hammett, H. L. and B. F. Barrentine, 1961. Some effects of baking upon the carbohydrate content of sweet potatoes, Proc. Am. Soc. Hort. Sci. 78: 421-26.

2. Horowitz, W, 1980. Official methods of analysis. Association of Official Analytical Chemists, 13 th ed. Washington, D.C.

3. International Institute of Tropical Agriculture, 1980. Annu. Rep., Ibadan, Nigeria.

4. Jenkins, W. F. and E. L. Moore, 1956. Carbohydrates and ascorbic acid in sweet potatoes as affected by time and sampling techniques, Proc. Am. Soc. Hort. Sei. 67: 490-92.

5. Olson, A. C., G. M. Gray, M. R. Gumbmann, C. R. Sell and J. R. Wagner, 1980. Factors Causing Flatulence in Legumes, pp. 275-94. In: Ory, R. L., Ed, Antinutrients and Natural Toxicants in Foods. Food \& Nutrition Press, Inc., Westport, Conn.

6. Palmer, J. K., 1982. Carbohydrates in sweet potato, pp. 134-40. In: Villareal, R. L. and T. D. Griggs, Eds, Sweet Potato. Proc. First Inter. Symp. Asian Veg. Res, Dev. Cent., Shanhua, Tainan, Taiwan.

7. Rao, V. N. M., D. D. Hamman and E. G. Humphries, 1975 , Mechanical testing as a measure of kinesthetic quality of raw and baked sweet potatoes, Trans. Am. Soc. Agrie. Eng. 17: 1187-88.

8. S101 Technical Committee, 1980. Sweet potato quality, South. Coop. Ser. Bull. 249. Russell Res. Cent., Athens, Ga.

9. Swingle, H. D., 1966. The relation of pectic substances and starch to consistency and moistness of sweet potato, PhD dissertation, La State Univ.

10. Tsou, S. C. S. and R. L. Villareal, 1982. Resistance to eating sweet potato, pp. 37-44. In: Villareal, R. L. and T. D. Griggs, Eds, Sweet potato. Proc. First Int. Symp., Asian Veg. Res, Dev. Cent., No. 82-172. Taiwan.

11. Villareal, R. L., 1982. Sweet potato in the tropics-progress and problems, pp. 3-16. In: Villareal, R. L. and T. D. Griggs, Eds, Sweet potato. Proc. First Int. Symp., Asian Veg. Res. Dev. Cent., No. 82-172. Taiwan.

12. Walter, W. M., Jr., A. E. Purcell and A. M. Nelson, 1975. Effects of amylolytic enzymes on "moistness" and carbohydrate changes of baked sweet potato cultivars, J. Food Sci. 40: 793-96. 